Board of Governors of the Federal Reserve System

International Finance Discussion Papers

Number 547

April 1996

\title{
GERMAN UNIFICATION: \\ WHAT HAVE WE LEARNED FROM MULTI-COUNTRY MODELS?
}

Joseph E. Gagnon, Paul R. Masson, and Warwick J. McKibbin

NOTE: International Finance Discussion Papers are preliminary materials circulated to stimulate discussion and critical comment. References in publications to International Finance Discussion Papers (other than an acknowledgment that the writer has had access to unpublished material) should be cleared with the author or authors. 
DATA ENTRY FORM: $\underline{\text { AWPE }}$

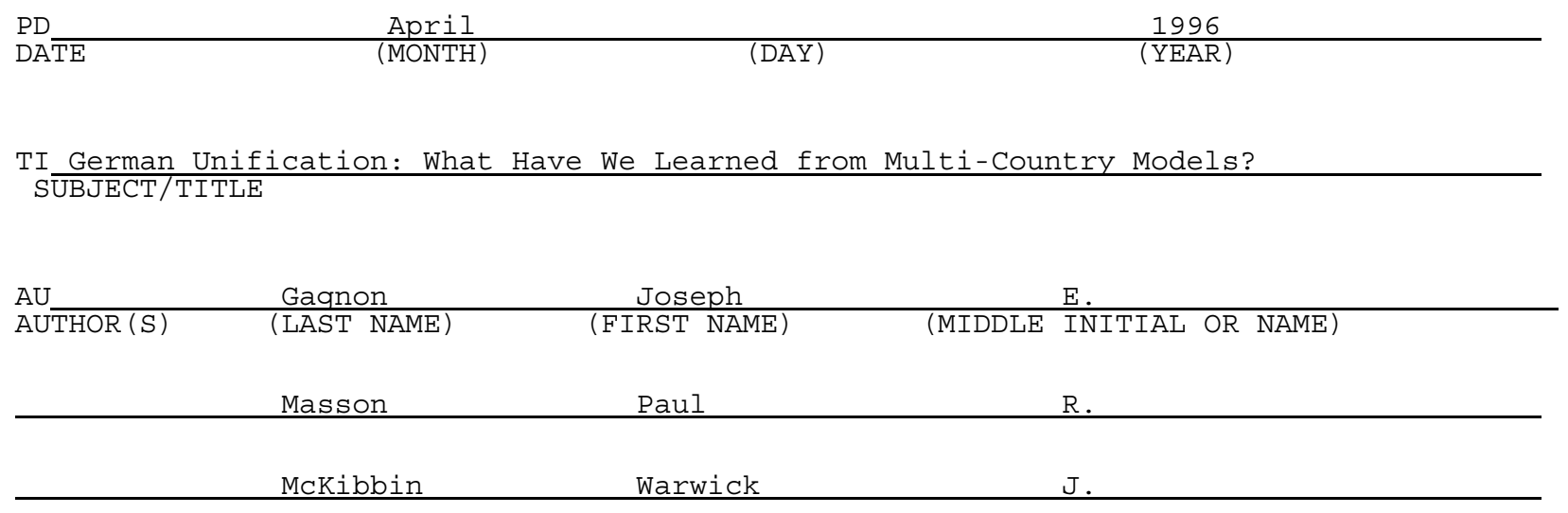

AA Gagnon: Division of International Finance, Board of Governors of the Federal AUTHOR'S AFFILIATION

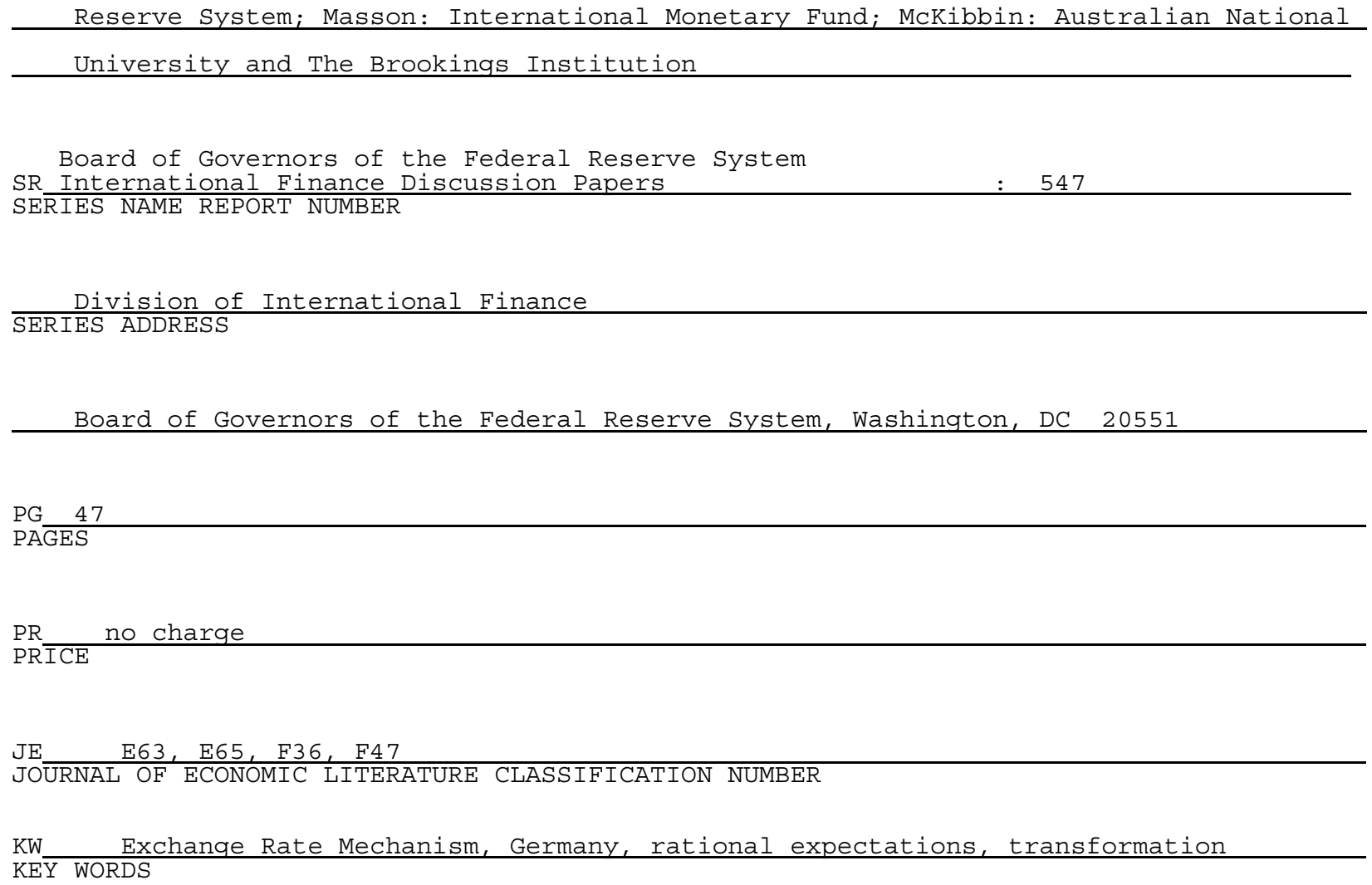

$A B$

ABSTRACT (Abstract follows.) 


\begin{abstract}
$\underline{\text { ABSTRACT }}$
This study reports on early simulations of the effects of German unification using three different rational-expectations multi-country models. Despite significant differences in their structures and in the implementations of the unification shock, the models delivered a number of common results that proved to be a reasonably accurate guide to the direction and magnitude of the effects of unification on most key macroeconomic variables. In particular, unification was expected to give rise to an increase in German aggregate demand that would put upward pressure on output, inflation, and the exchange rate, and downward pressure on the current account balance in Germany. The model simulations also highlighted the contractionary effects of high German interest rates on other member countries of the Exchange Rate Mechanism of the European Monetary System.
\end{abstract}




\title{
German Unification: What Have We Learned from Multi-Country Models?
}

\author{
Joseph E. Gagnon, Paul R. Masson, and Warwick J. McKibbin ${ }^{1}$
}

\section{Introduction and Goal of the Paper}

The unification of East and West Germany gave rise to one of the largest and most abrupt economic transformations of any major industrial country in the postwar era. Between November 1989 and January 1991, unification went from being almost inconceivable to an established fact. During these months economic and political observers around the world scrambled to assess the likely implications of unification for Germany and the rest of the world.

One approach to exploring the economic implications was through simulation of macroeconometric models. Unification posed a major challenge to modelers, however, because it promised a fundamental structural change to the German--and particularly the East German-economy. This fundamental change was of a nature not observed before. For the first time a socialist planned economy was being transformed into a capitalist market economy, and the transformation was occurring almost overnight.

Given the potential importance of unification for the world economy, from the first there were a number of simulation studies of its effects. However, traditional models with backwardlooking expectations were not well suited to the task, because they did not allow for sharp anticipatory movements in asset prices. Already early in 1990 financial markets were trying to anticipate the future effects of unification, before any of its aspects (currency union, fiscal transfers, etc.) had occurred, and this produced a sharp rise in German interest rates.

${ }^{1}$ Gagnon is Senior Economist in the Division of International Finance, Board of Governors of the Federal Reserve System; Masson is Assistant Director in the Research Department, International Monetary Fund; and McKibbin is Professor of Economics at Australian National University and Nonresident Senior Fellow at the Brookings Institution. We are grateful to Claire Adams for research assistance, to Tessa van der Willigen for supplying some of the data, and to Wilfried Jahnke, Russell Kincaid, Donogh McDonald, and Ellen Meade for helpful comments. This paper reflects the views of the authors and should not be interpreted as representing the views of the Board of Governors of the Federal Reserve System, the International Monetary Fund, Australian National University, the Brookings Institution, or other members of their staffs. 
In this paper, we report on simulation studies prepared early in 1990 using a new generation of forward-looking multi-country models with rational expectations and explicit attention to both stock and flow equilibrium. Three models were the MULTIMOD model maintained by Paul Masson and colleagues at the International Monetary Fund; the MSG2 model maintained by Warwick McKibbin at the Brookings Institution; and the MX3 model maintained by Joseph Gagnon at the Board of Governors of the Federal Reserve System. These modeling groups investigated a variety of aspects of German unification with models having some basic similarities but using very different approaches to incorporating the shock of unification into their models.

The goal of this paper is to determine what lessons can be learned by comparing the early model simulations of unification with the macro data for Germany and the rest of the world in the five years since unification. The potential lessons can be divided into two categories: First, what aspects of unification were well captured by the models, and can the associated model properties be used to inform policymakers in the future? Second, what aspects of unification were not adequately described by the models, and can modelers improve their future performance? In particular, where the models did not perform well, was this due to government policies that were different from those assumed, or, instead, to structural deficiencies in the models or in the implementation of the unification shocks?

\section{An Overview of Developments Since Unification}

This section provides a capsule summary of the evolution of the main macroeconomic variables since economic unification in July 1990. For some variables, unification has produced breaks in series, which make interpretation more difficult. Nevertheless, an overall picture emerges of a sharp fall in East German output, followed by a period of sustained growth that is faster than in the West. Investment is relatively strong in the East, but large fiscal transfers continue from West to East. West Germany faced an initial period of strong demand and 
inflationary pressures, countered by a restrictive monetary policy that raised interest rates in Germany and across Europe, and contributed to strains in the European Monetary System (EMS) and the crises of 1992-93. A European recession occurred in 1992, followed by a recovery of growth which nevertheless leaves unemployment high in a number of countries, including Germany.

A. Output and Inflation

Unification was accompanied by a continuation of the high output growth seen in Germany and in Europe generally in the late 1980s (Chart 1). However, demand pressures in Germany began to put upward pressure on inflation in Germany, raising the rate of growth of the CPI to almost 6 percent by the end of 1991. The boom in output was followed by a short, sharp recession in 1993, with a resumption in growth in 1994.

In East Germany, there was an initial sharp fall in output, as the shift to the market economy made many products uneconomic. However, starting in 1991, annual output growth in the East has been in the 5-10 percent range, consistently higher than in the West (Chart 2). Output in the East was sustained by strong investment growth (Table 1). Inflation rates in the East were high initially, accompanying major changes in relative prices of various goods and services, as well as large wage increases. By 1994, however, the rate of inflation was comparable to that in the West.

\section{B. Monetary and Exchange Rate Developments}

At the time it was announced in February 1990, the conversion rate of one ostmark to one deutschemark (DM) for assets ${ }^{2}$ and wages generated concerns that this would create inflation as well as make East German salaries uncompetitive. These concerns were soon seen to be unfounded, as the size of the German money supply increase was not greatly out of line with the size of the East German economy. Moreover, though East German salaries were not competitive

\footnotetext{
${ }^{2}$ The one-to-one conversion rate applied to a limited amount of monetary claims only--the average conversion rate for the banks' balance sheets was about 1.8 to 1 .
} 
at the conversion rate, they were made even less competitive by the subsequent actions of the trade unions, which aimed to equalize salaries across Germany and obtained large subsequent wage increases (see below).

Though the conversion of ostmarks did not present an inflationary problem, the German money supply did grow strongly in the 1991-94 period, at times exceeding 10 percent on a twelve-month basis (Chart 3), as excess demand led to strong growth in nominal income; in addition, there were shifts out of other assets into M3, making the latter a less reliable indicator. Since German monetary targets involved keeping monetary growth for the year in the range of 3.5-5.5 (1992), 4.5-6.5 (1993), and 4-6 (1994), the Bundesbank raised short-term interest rates steadily over the 1990-92 period (Chart 3, bottom panel). However, long-term rates in Germany started declining from the end of 1990.

Short-term interest rates in other European countries also rose over this period, and in particular in countries that participated in the Exchange Rate Mechanism (ERM) of the EMS. These increases in interest rates were accompanied by increased tensions in the ERM, since the cyclical situation of countries outside Germany did not justify the same tight monetary policy pursued by the Bundesbank, leading to doubts about their commitment to their parities against the DM. The September 1992 ERM crisis led to the withdrawal of the U.K. pound and the Italian lira from the ERM and a series of subsequent devaluations of currencies that remained in the mechanism, in particular the Spanish peseta, the Portuguese escudo, and the Irish pound. Further tensions in the summer of 1993 led to the widening of ERM bands to 15 percent early in August, and several currencies depreciated beyond their previous lower margins. As a result, the DM appreciated strongly in 1992-93 in real effective terms, both against ERM currencies and more generally (Chart 4). Already, strong demand pressures in Germany had led to a sharp decline in its current account position, from a surplus of over 4 percent of GDP in 1989 to a deficit of around 1 percent in the 1991-94 period (Chart 4).

C. Wages and Employment 


\section{$-5-$}

The boom in economic activity in West Germany led to a steady reduction of the unemployment rate, to about 5.5 percent in 1991 (Chart 5). Excess demand for labor was associated with sustained growth in real wages. In East Germany, the shock of unification produced a large increase in unemployment, from the negligible levels that prevailed before unification. Despite unemployment rates that were persistently in the 10-20 percent range, real wages grew very strongly in East Germany (Chart 6). From 1991Q1 to 1994Q4, the average annual increase in real wages was about 13 percent. Thus, initial disparities in unit labor costs were exacerbated by negotiated wage increases, and, as a result, there was no employment growth until 1994, even relative to the low levels of employment that prevailed soon after unification.

\section{Fiscal Policy}

It was clear from the start that unification would involve large government transfers from the West to the East. However, their size and persistence were greater than most initial estimates. Total transfers, either gross or net of federal taxes paid in East Germany, grew steadily over the 1991-94 period, and by 1995, they constituted 5 percent of West German GDP and 41 percent of East German GDP (Table 2). About 60 percent of the transfers constituted support for consumption and social purposes, and 40 percent was support for public and private investment. The latter includes investment subsidies and grants, accelerated depreciation, and loans for investment purposes on subsidized terms.

Despite the enormous burden on the budget, Germany was relatively successful in limiting the increase in the overall budget deficit, through a combination of cuts in other spending (including low public-sector wage increases), and, especially, through tax increases (Table 3). An important component of the latter was the "solidarity" surcharge on income tax of 7.5 percent reimposed in 1995. As a result, the general government deficit in that year is estimated at 3.6 percent of GDP, with the inclusion for the first time of interest costs of the Treuhand (which had been off budget before). 


\section{E. Restructuring the East German Economy}

Despite major progress in integrating the East German economy, the tasks remaining are considerable. Clearly, a first priority was to reduce the extent of state ownership and to convert the economy to private ownership. This was the task of the Treuhand, which has restructured, sold, and, where necessary, closed existing state-owned enterprises. Despite initial problems due to the lack of transparency concerning property rights and the need to attempt restitution of property expropriated by the former communist regime, it has achieved its mandate, having disposed of over 13,000 businesses.

Moreover, new investment has been flowing into East Germany, and there are reports that new plants operating in the eastern part of Germany are as profitable as those in the West. However, average profitability levels clearly remain much below those in the West. Using data on potential output and potential man-hours-worked from the Bundesbank (Monthly Report, August 1995), output per man-hour at normal utilization rates amounted in 1994 to 64.4 DM (at 1991 prices) in the West, and only 21.5 DM in the East. Thus, East German labor productivity is only about one-third that in the West. Clearly, an extended period of investment is needed to raise the capital stock sufficiently to equalize productivity (and also, presumably, to provide training in areas not emphasized by the former regime). The transition process will also have to involve a reduction in government subsidies and income transfers to the East. Hence the challenges remain large.

\section{The Models and Methods of Simulating the Impacts of Unification}

In this section we summarize the models used in the early studies of German unification and give an overview of the approach and results of each of the original studies. This overview is important because the studies were each undertaken independently in a period of great uncertainty about how the unification process was going to develop both politically and economically. One common aspect of the studies is that unification was viewed as involving a 
substantial aggregate demand shock to Germany. The studies focused on important issues that would likely emerge such as the large worsening of the German current account, high interest rates in Germany and rising real long-term interest rates throughout the world, and significant pressure to be placed on countries within the ERM as they attempted to maintain parity while the DM appreciated significantly.

The three models discussed in this paper share a number of common features, which, in turn, generate a high degree of similarity in their simulations of unification. One of the key characteristics that differentiates these three models from many other empirical macroeconomic models is that each assumes that expectations are "rational" in the sense that expected future variables are set equal to the model's prediction of these variables in the absence of shocks. The models focus on the main components of the national income accounts of individual countries or groups of countries aggregated together. Consumption is determined by expected permanent income and the real long-term interest rate. Investment is driven by the current and expected future marginal product of capital relative to the cost of capital, subject to adjustment costs. Government spending is exogenous, but a tax reaction function stabilizes the ratio of government debt to GDP. Goods produced in different industrial countries are assumed to be imperfect substitutes, so that trade flows respond to relative prices and aggregate demand in the importing country.

In the short run, output may deviate from potential. In the long run, prices adjust to return output to its sustainable level, which is a function of capital, labor, and technology. Price adjustment is primarily determined by an expectations-augmented Phillips curve or a forwardlooking staggered-contracts model operating either on prices or indirectly through wages. Stocks of physical capital, government debt, and net foreign assets are cumulated from the relevant flow variables. Technology and labor supply are exogenous, at least in the long run. The long-run equilibrium is essentially that of a Solow growth model. Long-term interest rates are determined 
by expected future short-term rates. Capital is assumed to be perfectly mobile between industrial countries so that exchange rates obey the open interest parity condition.

The primary areas of differences across the models are the country coverage, the data frequency, the adjustment dynamics, the estimated coefficients, and the specification of monetary policy.

\section{A. MULTIMOD}

MULTIMOD includes separate submodels for each of the Group of Seven countries, for the remaining industrial countries as a group, and for the developing countries (divided into capital exporting and capital importing countries). ${ }^{3}$ The model uses annual data. In MULTIMOD, consumption behavior incorporates both a forward-looking permanent income component and a myopic component that responds to current disposable income. The sensitivity of consumption to current income permits fiscal policy to be expansionary, as in traditional Keynesian models, though to an extent that depends on the estimated coefficient of disposable income. In most submodels, the monetary authority is assumed to move short-term interest rates in response to deviations of the main monetary aggregate from its targeted level. In the case of Germany, this aggregate is M3. In the case of other ERM countries (France, Italy, and the smaller industrial country group) the monetary authority moves the short-term interest rate to limit deviations in the exchange rate from its parity with the DM.

The approach used in simulating German unification in MULTIMOD was to treat the excess of spending over output in East Germany and the migration from the East to the West as the main "shocks" to the global economy associated with unification. ${ }^{4}$ It was assumed that, as of 1990, the scale of the transfers from West Germany to the East was fully anticipated. No attempt

\footnotetext{
${ }^{3}$ See Masson, Symansky, and Meredith (1990) for a description of MULTIMOD Mark II.

${ }^{4}$ See Masson and Meredith (1990a, 1990b). The two studies differ in the following ways: the earlier, unpublished version used preliminary estimates of the size of transfers from West to East Germany that were smaller than those in the published paper by about one-quarter, while the simulation of a "European monetary policy" was removed from the published version.
} 
was made to expand MULTIMOD to include East Germany; instead, exogenous inputs were used to quantify the increase in demand for West German goods (and those of other countries) that was expected to result from German unification.

Turning to the magnitude of the shocks, Table 4 presents two sets of assumptions of the fiscal transfers from the West and the increased net import demand in East Germany that were assumed to result from unification. ${ }^{5}$ In the first one, which was termed the "reference case," investment was assumed to proceed at a rapid enough rate to raise output per worker in East Germany to 80 percent of the level in the West by 2001. In the second--less optimistic--scenario, investment in the East was assumed to be lower but saving was also lower, and output per worker reached only 60 percent of West Germany's level in 2001. It was assumed that in the absence of unification, the current account position of East Germany would have been roughly in balance, so the figures in Table 4 constitute additional demands on world saving. The baseline also assumed potential GDP growth of 2 percent in the East and 2.75 percent in the West. It should be noted, by comparison with Table 2, that both the magnitude and the persistence of the transfers to East Germany were greatly underestimated in the simulations.

Another significant aspect of unification was the re-establishment of free mobility between East and West Germany, resulting in substantial westward migration. The last few months of 1989 saw large population flows from the East, and substantial migration continued early in 1990. In the reference scenario, net migration from East to West Germany was assumed to be 280,000 in $1990,100,000$ in $1991,70,000$ in $1992,40,000$ in 1993 , and 20,000 a year thereafter. In the less optimistic scenario with lower investment in the East, net migration was assumed to be the same in 1990-91, but to be considerably higher from 1992 onward: 270,000 in that year, 220,000 in 1993, and declining to 90,000 in the year 2001.

\footnotetext{
${ }^{5}$ These assumptions were based on contemporaneous work by McDonald and Thumann (1990).
} 
Migration was expected to lead to increases in both aggregate demand and supply in West Germany; the corresponding declines in the East were embodied in higher projected net imports. In MULTIMOD potential output is described by a production function that depends on capital and labor with constant returns to scale. For a given capital stock, migration would affect potential output through the induced increase in the labor force, times the marginal product of labor; in the longer run, capital should increase with the labor force and potential output rise proportionately. The labor force increase was calculated as the population increase times the participation rate. In the reference case, the level of potential output was projected to be 1.25 percent higher in West Germany by the year 2001 than it would have been in the absence of migration. In the less optimistic scenario, it was projected to be 4 percent higher, as a result of the larger migration.

The simulations highlighted three factors that were important in determining how much of an increase of demand from East Germany would show up in the form of increased output in West Germany, how much as lower combined German net exports, and how much as higher inflation: (1) the stance of monetary policy, (2) the influence of the level of capacity utilization on inflation, and (3) the interest elasticities of domestic components of demand.

It was recognized that the conduct of monetary policy could have been affected by currency union because (among other reasons) the income velocity of money might not be the same in the two parts of Germany. Rather than attempting to quantify those effects, it was assumed for the purposes of the simulations that targets would be appropriately adjusted to take into account velocity shifts and other factors that would otherwise affect the relationship between interest rates and economic activity.

Concerning the effects of an increase in demand on inflation and output, productive capacity is not an absolute constraint on output in MULTIMOD. Instead, the higher is the rate of capacity utilization, the greater are pressures on inflation. Moreover, the model implies a fairly flat (and linear) output-inflation tradeoff. Alternative simulations using a steeper, nonlinear 
tradeoff yielded slightly more inflation and slightly less output than the reference scenario, but the overall nature of the results was quite similar.

The effects of the unification shock depend importantly on the interest elasticities of

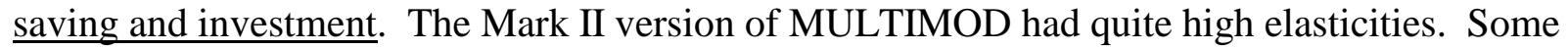
other evidence on Germany and other countries suggested that saving and investment might not be as sensitive to interest rates. The MULTIMOD simulations were performed using revised equations for consumption and investment (subsequently incorporated in the standard model) that embodied lower interest-rate effects than in the original Mark II model, making the results more consistent with this empirical evidence.

\section{The Reference Scenario (Table 5)}

The reference simulation of unification assumed that net imports into East Germany would increase by amounts given in column 3 of Table 4. This increase in demand was assumed to show up in the first instance in increased exports by West Germany (two thirds of the amount) and by other countries (the remaining one third, allocated on the basis of historical shares in imports of West Germany). The combined government deficit as reported here includes all unification-related government expenditures, as well as higher interest payments due both to a larger debt stock and to higher interest rates. In the reference case, tax $\underline{\text { rates }}$ are assumed to be the same as in the baseline, which assumes no unification. However, tax revenues are elastic, and increase roughly in proportion to GDP. The simulations also include the projections of migration from the East to the West described above, and the resulting increases of potential output in the West.

\section{A Less Optimistic Scenario with Slower Growth in East Germany (Table 5)}

In an alternative, less optimistic scenario for unification, investment was assumed to be less buoyant. As a result, productivity growth converged less quickly, and by the year 2001, the productivity gap between East and West Germany would still be about 40 percent. Net imports by the East were not very different initially from those in the reference case (see Table 4), but the 
East's trade deficit would persist longer because output would not rise as much in the medium term. Correspondingly, income and saving are also lower there.

In this scenario, real incomes are assumed to be lower in East Germany, and emigration higher than in the reference scenario: extra net emigration from the East to the West amounts to 200,000 in $1992,180,000$ in 1993 , and gradually declining amounts thereafter (in addition to the projected migration in the reference scenario). Government expenditures in the West are assumed to be higher as a result of the increase in population relative to the reference scenario (due to increased expenditure on housing and social services, for instance). Unemployment benefit payments are also higher in the East, as a result of higher unemployment.

\section{An ERM Realignment (Table 5)}

The reference scenario suggested that an appreciation of the DM of about 4 percent against the U.S. dollar might result from unification. With fixed central parities with respect to other currencies participating in the ERM, real appreciation of the DM resulted from a combination of nominal appreciation against non-ERM currencies (principally the U.S. dollar and the yen), increases in prices in Germany, and a tendency to deflation in other ERM countries. It was suggested in Masson and Meredith (1990b) that the tightening of monetary conditions in other ERM countries might be avoided by a realignment vis-à-vis the DM, also in principle permitting a smoother allocation of the increased demand from East Germany among European countries. The upward realignment of the DM would tend to remove some of the short-run pressure on existing capacity in Germany. These favorable effects, it was argued, would however have to be balanced against the negative effects of higher inflation in the short run in other ERM countries, and consequently a possible loss of credibility of their commitments to price stability and to "hard currency" policies. A realignment scenario was presented in which a depreciation of 4 percent of the other ERM currencies vis-à-vis the DM occurred in 1991, but had unfavorable effects on expectations of future exchange rate movements and inflation differentials. Specifically, the other ERM currencies were expected to depreciate by a further 1 
$1 / 2$ percent a year against the DM in the years following the initial realignment, similar to the periodic realignments that were observed in the early years of the EMS.

\section{B. MSG2}

The version of the MSG2 model used in the original study included submodels of the United States, Japan, Germany, the Rest of the EMS (REMS), the Rest of the OECD, the non-oil developing countries, and the oil-exporting developing countries using annual data. ${ }^{6}$ As in MULTIMOD, consumption in MSG2 depends on both permanent income and current disposable income. In most submodels, the monetary authority sets an exogenous path of the main monetary aggregate and the short-term interest rate is determined through the money demand equation. In the REMS submodel the monetary authority pegs the exchange rate to its parity with the DM.

The goal of the study reported in McKibbin (1990) and updated in McKibbin (1992) was to examine the impact on the global economy, in particular global asset markets, of the real transfer required to raise East German living standards toward those of West Germany. In particular the paper focused on the difference between financing the real transfers by fiscal versus monetary measures in Germany and the impact of the ERM on the adjustment of the world economy. The paper attempted to place some preliminary empirical magnitudes on possible alternative scenarios for German unification. The paper focused on the implications for aggregate demand and supply in a unified Germany and how these spill over into the rest of the world. It was not intended to provide a specific forecast of the likely outcomes of unification but to focus on alternative scenarios. A further objective was to directly address the debate in the financial press about "unexplainable" movements of real long-term interest rates and exchange rates from the end of 1989. The paper illustrated that the co-movements of asset prices within countries and between countries depend on the nature of actual and expected shocks.

The basic hypothesis of the paper was that the policy response of making the East German currency convertible would do little to stem the tide of people moving from East to

\footnotetext{
${ }^{6}$ For a description of MSG2, see McKibbin and Sachs (1991).
} 
West. What was inevitable was going to be a transfer of physical capital from West Germany to East Germany in order to raise the marginal product of labor in East Germany. It was argued that this transfer could be accomplished in a variety of ways. Firstly, attracted by lower East German labor costs, private capital could flow into East Germany. Secondly, if wages in East Germany were raised artificially to West German levels, the West German government could effect the transfer of real resources from West to East via direct subsidies to employment in the East so that private capital would find it attractive to invest there despite the lower labor productivity. Under either scenario, there were going to be significant fiscal implications of granting East Germans West-German unemployment and social security benefits.

To understand the different implications for aggregate demand and supply the paper examined a number of scenarios in turn.

\section{Fiscal Expansion (Table 6)}

With elections looming in West Germany and promises of tax cuts, it was argued that these fiscal measures were likely to be financed through a larger German fiscal deficit. The first scenario considered the consequences of a substantial expected German fiscal expansion resulting from direct subsidies or unemployment compensation paid to East Germany. The fiscal expansion was assumed to equal 1.7 percent of baseline GDP in 1990 and 3.3 percent of baseline GDP from 1991 onwards. These scenarios focused on the implications of expansionary fiscal policy for the West German economy and they modeled the transfer as an increase in West German government consumption that was handed over to East Germans.

\section{Fiscal Expansion with ERM Realignment (Table 6)}

The second scenario was the same as scenario 1 except that the DM was allowed to appreciate against the U.S. dollar and against the other ERM currencies which remain approximately unchanged relative to the U.S. dollar.

\section{Monetary Expansion (Table 6)}


The third simulation was a relaxation of German monetary policy. This could be interpreted as the result of currency unification with an unrealistically strong exchange rate for East German prices and wages and no other direct measures for East Germany. In this case, it is likely that a severe slowdown would result in East Germany (still not explicitly part of the model) and that this would lead to pressure on the Bundesbank to ease policy. Abstracting from money demand changes originating in the East, scenario 3 considered an increase in the money growth rate of 2 percent per year.

\section{Supply Side Effects (Table 6)}

The final scenario was intended to capture the possible macroeconomic consequences for the world economy of the supply-side effect of a completely unified Germany; both the East German capital stock and work force were incorporated into the West German economy. This simulation assumed no adjustment in fiscal and monetary policies in the new Germany in excess of the policies in place in West Germany before unification. In other words, the fiscal balance changes little and the money supply was raised by enough to keep German interest rates almost unchanged in the face of the increase in aggregate supply. It assumed that East German labor was integrated into West Germany at the West German wage rate despite a large productivity differential. The stickiness of wages initially led to severe unemployment, despite assuming full employment of existing East German physical capital. In the long run, wages adjusted and physical capital was put in place to absorb the unemployed according to standard neoclassical growth theory. In the short run, severe dislocation of resources resulted. This scenario showed the extent of the problem of attempting to integrate two economies with very different productivity levels, quickly and without restrictions. It was argued that the results showed clearly that attempting full integration in the way predicted would be potentially disruptive, but it would not automatically be ruled out due to political considerations. It was argued to be a useful benchmark for evaluating alternatives.

C. $\underline{\mathrm{MX} 3}$ 
The MX3 model includes submodels of the United States, Germany, Japan, and the rest of the world (ROW) using quarterly data. ${ }^{7}$ Unlike MULTIMOD and MSG2, MX3 does not include a component of consumption that is proportional to current disposable income. Instead, consumption in MX3 follows a lagged adjustment to its forward-looking permanent income level This property makes output in MX3 much less sensitive to fiscal policy than in the other two models. In MX3, the monetary authorities are assumed to move short-term interest rates in response to deviations of a target variable from its targeted level. In the simulations of German unification, monetary policy was assumed to target the price level in most cases.

In MX3, German unification was modeled by augmenting the supply equations in the West German model to include East German factors of production. This modification required not only changing the structure of the supply side but also choosing the baseline levels of important variables and parameters. Choices regarding these magnitudes determine both the speed with which the East German economy converges with the West German economy and the strength of the spillover effects on other countries. The critical assumption was that East Germany brings relatively more labor than capital to the union, creating a substantial differential between the capital-labor ratios in the two regions. As a result, unification increased German aggregate demand--primarily through increased investment and consumption--more than it increased German aggregate supply.

Two studies of German unification were conducted with MX3. The results presented here are drawn from Adams, Alexander, and Gagnon (1993), which is the published version of International Finance Discussion Paper No. 421, January 1991. An earlier study, Alexander and Gagnon (1990), reached similar conclusions but did not consider the implications of unification for ERM countries. ${ }^{8}$ One difficulty in examining the effect of unification on ERM countries is

${ }^{7}$ For a description of the MX3 model, see Gagnon (1991).

${ }^{8}$ Other significant differences between the two studies are that the later study assumed lower values for East German capital and technology and it allowed for persistent unemployment in East Germany as unions pressed to catch up to West German wage levels. These differences led 
that MX3 consolidates the non-German ERM countries with all other countries in the ROW block. The approach taken was to obtain some boundaries on the ERM effect by running simulations in which ROW has a freely floating exchange rate and compare them to simulations in which ROW pegs its exchange rate to Germany's.

The most significant changes to the model involved adding separate expressions for East German capacity, fixed investment, and labor supply. Productive capacity in East Germany was modeled as a Cobb-Douglas function of East German technology, capital, and labor. The East German labor force was set at 30 percent of the West German labor force in 1990 and it was assumed to remain constant over time while the West German labor force was assumed to grow at 0.5 percent per year. East German labor productivity was assumed to be one-third that of West Germany. This lower productivity was modeled as due to both lower technology and a lower capital-labor ratio in East Germany. After unification, the East German technology factor was assumed to exogenously converge to the West German level over five years. Alternative simulations were conducted to examine the sensitivity of the results to different assumptions about the level and rate of convergence of East German technology. Investment in East Germany was modeled as a stock-adjustment process designed to gradually raise the East German capital stock until the marginal product of capital is equal to that of West Germany.

In the West German sector of MX3, equilibrium labor supply is simply a constant fraction of the exogenous labor force. In order to model the initial increase in East German unemployment, an "effective" East German labor supply was constructed that was a negative function of the excess of West German over East German wages. Labor demand in both parts of Germany was determined by aggregate demand in the short run and by equalizing the marginal product of labor with the real wage in the long run. Together, labor demand and labor supply implied that the NAIRU would be higher in East Germany as long as wages were lower than in

to a modest quantitative--but no qualitative--change in the model simulations of key German macroeconomic variables. 
West Germany. There was assumed to be no net migration between the two parts of Germany after $1990 .^{9}$

The simulation results for unified Germany are expressed relative to a baseline in which the labor productivity of East Germany is fixed at one-third that of West Germany. The unification shock is implemented by augmenting the German supply sector as described above and by raising government spending exogenously. These shocks have an immediate effect on private aggregate demand. Consumption increases because the new expectation of a more productive future East Germany raises permanent income. Investment increases due to the higher marginal product of capital in East Germany.

\section{The Reference Scenario (Table 7)}

In the reference scenario, fiscal policy was modeled by setting government spending in unified Germany equal to that of baseline West Germany on a per-worker basis. This implied a large increase in government spending relative to the combined baselines of East and West Germany. Over time, the tax reaction function ensures that the ratio of government debt to GDP returns to its baseline level. In simulations, the tax reaction function eliminated the fiscal deficit more quickly than in the real world, since a large deficit still remains in 1996. Alternative simulations were conducted with a more persistent fiscal deficit, but the main conclusions were little affected because the forward-looking consumers in MX3 are only mildly sensitive to the time path of taxes, i.e. MX3 is close to Ricardian equivalence. In the reference scenario, exchange rates are freely floating between all countries.

\section{ERM Scenario (Table 7)}

Scenario 2 augmented scenario 1 with an approximation of the ERM effect. In this scenario, the short-term interest rate in ROW was assumed to target the exchange rate with Germany.

\footnotetext{
${ }^{9} \mathrm{An}$ alternative simulation showed that the results for unified Germany were relatively insensitive to migration (1 million workers were assumed to migrate from East to West over a five-year period).
} 


\section{ERM Scenario with Accommodative Monetary Policy (Table 7)}

Scenario 3 combines scenarios 1 and 2 with accommodative German monetary policy. In this scenario the Bundesbank raises its price level target by 1 percentage point per year for three years.

\section{Results from the Models and Key Issues Raised in the Early Studies}

In section III we outlined three studies, focusing on the characteristics of the models, the approach to modeling unification, and the issues that were addressed. In this section we present some key results from each model and draw out some overall lessons from the studies and their implications for model development and policy formulation. The results from each study depended on the model used as well as the assumptions about likely developments in Germany from 1990 forward. A surprising aspect of the results was that there was a great deal of consensus across these studies about some aspects of unification that subsequently emerged as important issues after the studies were completed. These aspects were ignored by many commentators at the time and are still ignored by some analysts who argue that no one could have foreseen the problems that emerged in unifying the two Germanies.

Tables 5 through 7 present results for a number of variables for each model from 1990 to 1997 or later. Detailed descriptions of each scenario can be found in section III above. Table 5 contains standardized results for MULTIMOD, Table 6 contains standardized results for MSG2, and Table 7 contains standardized results for MX3. We have selected variables that each model can produce, although in some cases the selected variables were not presented in the original studies. In these cases, the selected variables were calculated using other variables that were included in the original studies. The variables presented are for: United Germany (GDP, current account, and fiscal balance), West Germany (GDP, inflation, real effective exchange rate, and real long-term interest rate), and other ERM countries (GDP and inflation). 
Each variable is expressed either as a percent deviation from baseline (e.g. GDP), a percent-of-GDP deviation from baseline (e.g. current account, fiscal balance), or a percentage point deviation from baseline (e.g. inflation, interest rates). Each scenario produced by the models is given a scenario number based on the assumptions discussed in section III above. The scenario ordering is based on the original studies and is not necessarily the same across models.

These tables can be compared by focusing either on the differences between results or on similarities. However, a true comparative analysis is difficult because each study undertook different simulations under different assumptions about policy responses. Nonetheless, we can draw out the major mechanisms from each model.

First, each study presumed that there would be a significant fiscal expansion in Germany although the size and persistence of the fiscal stimulus varied across models. This aspect of unification is illustrated for MULTIMOD and MX3 in each scenario, and in MSG2 in scenarios 1 and 2. In the MULTIMOD results for scenario 1 and 3 and all the MX3 results the fiscal deterioration lasts for up to 5 years whereas, in the MSG2 scenarios and MULTIMOD scenario 2, the fiscal stimulus is more permanent. Despite these differences in assumptions, the adjustment process is essentially similar across the models. The announcement of the fiscal stimulus in Germany raises real and nominal long-term and short-term interest rates in Germany. In roughly comparable scenarios real long-term interest rates rise between 80 and 130 basis points in each model.

The rise in interest rates leads to a capital inflow that appreciates the DM in both real and nominal terms. The rise in the real effective exchange rate is somewhat more dispersed across models, ranging from a low of 2 percent for the MULTIMOD reference scenario to a high of 11 percent for the MX3 scenarios that peg the German-ROW exchange rate. The capital inflow and exchange rate adjustment are reflected in a deterioration in the German current account of between 2 and 3 percent of GDP across the models. The first clear message from the models was 
that the adjustment process of getting the required resources into Germany would be via a deterioration in the current account facilitated by an appreciation of the DM.

The fiscal aspect of unification would tend to raise GDP and inflation in Germany relative to what they otherwise would have been. In contrast to MULTIMOD and MX3, the results for MSG2 have output lower than otherwise and inflation lower in 1990 but if combined with some monetary stimulus this result for MSG2 disappears. The reason for this result in MSG2 from the purely fiscal shock is that the anticipated fiscal program crowds out private investment in 1990 before the full spending increase begins. In addition the appreciation of the DM lowers imported goods prices which reduces inflation initially.

The models also show that the extent of output, price, and exchange rate change depends importantly on the assumption of the response of German monetary policy. Both the MSG2 and MX3 models showed that more monetary accommodation in Germany after 1990 leads to a larger rise in GDP and inflation and less appreciation of the DM.

Another lesson that is common to all three studies is the implication of the unification process in Germany for the other countries in the ERM. With upward pressures on the DM other ERM countries were forced to raise interest rates to maintain exchange rate parities. This tightening of monetary policy in the rest of Europe was contractionary for GDP and placed strain on the ERM. Comparison of scenario 3 and 1 for MULTIMOD, scenarios 2 and 1 for MSG2 and scenarios 1 and 2 for MX3 clearly illustrate this point. The extent of output loss for the rest of the ERM differs across models from between $0.4 \%$ to $3.9 \%$ (at the peak) relative to a range of 0 to $0.5 \%$ if an ERM realignment was implemented. Again, the size of results varies across the models because of model differences and different assumptions about the extent of fiscal adjustment in Germany. Nonetheless, this important lesson is amply demonstrated in these results. German unification was likely to be contractionary for the rest of Europe if ERM parities were maintained and there would be stress within the ERM as a result. 
The unanimity of the model results with respect to the ERM countries reflects four common properties shared by the models and their implementation of unification. First, unification led to a positive aggregate demand shock in Germany. Second, aggregate demand in each country is biased toward domestic goods. Third, goods produced in different countries are imperfect substitutes. Fourth, German monetary policy was assumed to target domestic nominal variables without regard for the behavior of these variables in other countries. ${ }^{10}$ Under these conditions, the ERM countries were forced to accept the same high interest rates and exchange rates as Germany without the benefit of the full aggregate demand shock that took place in Germany. The immediate conclusion is that the ERM countries faced a reduction in growth and inflation.

One interesting area of dissimilarity across these models is the long-run supply effect of unification on Germany's real effective exchange rate. In the standard trade equations used by most models, exports depend on foreign income and imports depend on domestic income. Since German unification implies a long-run increase in German income as technology transfer and capital accumulation raise East Germany's productivity toward the West German level, unified Germany tends to experience an increase in imports relative to exports unless the exchange rate depreciates in real terms. ${ }^{11}$

A supply-induced depreciation shows up strongly in MSG2 scenario 4. Scenarios 1 and 2 demonstrate that the real depreciation may be offset by fiscal expansion, but the appreciation

\footnotetext{
${ }^{10} \mathrm{~A}$ scenario reported in Masson and Meredith (1990a) showed that targeting a European monetary aggregate produced smaller negative output effects for the other ERM countries.

${ }^{11}$ Wyplosz (1991) made this argument in the context of a theoretical model. He also pointed out that a reduction in the German current account balance would lower net foreign assets in the long run relative to their position in the absence of unification, and that this should lead to a further depreciation of the real exchange rate. This net foreign asset mechanism is incorporated into all three sets of model simulations described here.
} 
caused by fiscal expansion is reversed over time while the depreciation caused by higher supply continues to grow, so that the DM must depreciate in the long run. The MULTIMOD scenarios incorporate aspects of both fiscal expansion and supply increase, and they exhibit a real depreciation of the DM, albeit a small one, in 2001. This property is absent from the MX3 simulations because the income elasticity of imports is a function of the cyclical position of income (i.e., relative to potential income). MX3 assumes that all trade flows grow in proportion to world capacity in the long run.

\section{Conclusions and Lessons for Policymakers and Modelers}

Table 8 gives some data for the macroeconomic outcomes over the 5 years of unification, 1990-94, and for the previous year. A comparison of 1989 with the subsequent years gives some indication of the results of unification--though of course other shocks or dynamic adjustment could explain why 1990-94 differed from 1989. ${ }^{12}$ There is some justification for doing so, nevertheless; 1989 was a normal year for Germany, and hence a good starting point--the fiscal position was in balance, inflation was roughly consistent with the Bundesbank's long-run target, and growth was reasonably strong.

Table 8 suggests that output growth and inflation in Germany were stimulated by unification, that interest rates rose and the DM appreciated, and that as a result the fiscal position deteriorated sharply and the current account went from a surplus of almost 5 percent to a deficit of one percent of GDP. These are stylized facts that accord well with the model simulations reported above. As expected, these effects seem to die out over time, though in several respects the outcomes, when compared to 1989 , differ from the model simulations of unification when compared to baseline. The sharpest difference is that output actually declined in 1993. None of

\footnotetext{
${ }^{12}$ An alternative procedure to evaluate the simulations would be to recreate the baselines actually used in the simulations reported in section III. However, this has the disadvantage of requiring three different evaluations; moreover, since the models considered are, for most purposes, close to linear, the baseline used is irrelevant.
} 
the models predicted a recession in 1993, although MULTIMOD did predict a modest reduction in the growth rate of West Germany relative to baseline. Other differences are predominantly a matter of timing, including the fact that the real effective exchange rate of Germany continues to appreciate through 1994 and inflation in Germany peaks in 1992-93.

One potential explanation for these differences is that none of the simulations adequately captured the interaction of inflation and monetary policy in Germany. The year-over-year German inflation rate increased by over 1 percentage point between 1990 and 1992, ${ }^{13}$ prompting a tightening of monetary policy that led to a recession in 1993 and the subsequent decline of inflation in 1994 and 1995. In contrast, many of the model simulations showed very little increase in inflation, and none of the simulations that did have higher inflation were able to match the timing of the realized data. It is not clear whether these discrepancies are due to errors in the price-adjustment sectors of the models or to misspecification of the behavior and credibility of the monetary authorities.

Another important question is the extent to which the recession in Europe can be attributed to German unification rather than to other causes. The model simulations highlighted the negative transmission effects on output in other European countries, and the actual outcomes indicate a slowdown in growth for the rest of the European Union which occurs much earlier than in Germany. Relative to 1989, the decline in output growth is 2.8 percent already in 1991. In this instance, the realized data appear quite favorable for the model predictions. Of course, other factors may have been at work, including drops in consumer confidence across Europe.

A related issue is whether the model simulations clearly anticipate the tensions in the ERM, which ultimately led to the crises of 1992-93. Though the directions of the effects--the increase in interest rates in Germany and the necessity for other ERM countries to raise rates in the face of downward pressures on output--are captured in these simulations, it must be

\footnotetext{
${ }^{13}$ The 12 -month inflation rate peaked considerably higher, as
} discussed above. 
recognized that the models cannot fully capture the induced effects on the credibility of these countries' commitments to their central parities, nor the reluctance of Germany to defend those rates. Therefore, the model simulations can be taken to be indicative of pressures, but they do not predict the response of policymakers to these pressures.

A further interesting question is whether the model results (or the exogenous assumptions) correctly captured the nature of the transformation process in East Germany. There are several aspects to this question. First, it seems that the size of the transfers that were needed from the West was larger than most commentators initially expected. Second, wage growth in the East much exceeded what was justified in terms of relative productivity levels. Third, and related to the second, output declines in East Germany were larger than anticipated.

The models differ in the extent to which they attempted to model developments in East Germany. The MULTIMOD simulations used the net imports generated from a separate real aggregate demand-supply model of East Germany as an estimate of the relevant shocks to the West Germany economy. MSG2 simulated different aspects of unification independently; one of these aspects was the supply-side effect of adding East German labor and capital to West Germany at West German wage rates. MX3 focused on the supply-side implications of unification with very little attention to the fiscal aspects.

Despite these differences, all the inputs to the model simulations embodied an overestimate of the output level in East Germany and an underestimate of the persistence of fiscal transfers to the East. These failures stem largely from an overly optimistic assumption about the effective value of the East German capital stock. This mistake was shared by most observers at the time, and is no doubt partly related to the assumption that wages would remain low. At higher wage rates, otherwise profitable plants were simply closed.

None of the models correctly anticipated the size and persistence of excess unemployment in East Germany. MSG2 scenario 4 highlighted the importance of the unemployment problem, but overestimated the adjustment speed to equilibrium. The second 
MX3 study made some progress on the persistence of unemployment, but only by modifying the model structure in light of data from late 1990.

As for migration from East to West--an issue highlighted only in the MULTIMOD simulations--this ceased to be an important factor after 1992, as can be seen from Table 8. Thus, the assumption of the less optimistic scenario that there would be continuing large net migration was not borne out. However, the reference case in Table 5 underestimated migration in 1990-91 by about 75,000 each year.

Altogether, the model simulations provided a reasonably accurate guide to the direction and magnitude of the effects of unification on most key macroeconomic variables. However, the model simulations were frequently wrong on the timing of these effects. The models tended to predict the strongest effects within a year or so after unification, whereas the data show that many of these effects required two or three years to reach their peak (though not long-term interest rates). This discrepancy is most likely due to the implementation of rational expectations as perfect foresight, in which agents are assumed to fully understand and anticipate all aspects of unification at the beginning of the simulations. One lesson for rational expectations modelers may be to incorporate learning behavior into the model when analyzing the effect of large and unusual shocks such as German unification (for a discussion of how to do so, see Hall (1993)).

It is always easier with hindsight to explain major economic events. In this paper we focused on a major economic event that is not only a fascinating study in economic adjustment in its own right, but that also produced data for evaluating a range of empirical issues. In particular, German unification provided us with the opportunity to evaluate the usefulness of a new generation of multi-country models that evolved during the 1980s. The experiment is interesting because the consequences of this major economic event were analyzed independently by three modelling groups using these new modelling tools and the results were made public in the very early stages of the unification process. The insights from these three models are still relevant in understanding the actual outcomes of German unification as well a range of other issues currently 
facing the world economy. Despite the widespread distrust of large scale modelling (primarily because of the poor performance of an earlier generation of demand-side models in the face of the oil price shocks of the 1970s) this particular exercise illustrates that the new generation of these models has proven useful in gaining insights of importance for policymakers. Our study also shows that the widely argued proposition that no one could have foreseen the consequences of German unification is an exaggeration. Indeed, there was a great deal of predictive material available from these three studies, as well as other academic papers based on the same underlying theories. 


\section{References}

Adams, Gwyn, Lewis Alexander, and Joseph Gagnon (1993) "German Unification and the European Monetary System: A Quantitative Analysis," Journal of Policy Modeling 15, 353-392.

Alexander, Lewis S., and Joseph E. Gagnon (1990) "The Global Economic Implications of German Unification," International Finance Discussion Papers No. 379, Board of Governors of the Federal Reserve System, April.

Gagnon, Joseph E. (1991) "A Forward-Looking Multicountry Model for Policy Analysis: MX3," Economic and Financial Computing 1,311-361.

Hall, Stephen (1993), "Modelling Structural Change using the Kalman Filter," Economics of Planning, 16, 1-13.

Masson, Paul R., and Guy Meredith (1990a) "Domestic and International Macroeconomic Consequences of German Unification," IMF Working Paper WP/90/85, September. , and ___ (1990b) "Domestic and International Macroeconomic Consequences of German Unification," Chapter VI of German Unification: Economic Issues, Leslie Lipschitz and Donogh McDonald, eds., IMF Occasional Paper No. 75, December.

Masson, Paul R., Steven Symansky, and Guy Meredith (1990) MULTIMOD Mark II: A Revised and Extended Model, IMF Occasional Paper No. 71, July.

McDonald, Donogh, and Günther Thumann (1990) "East Germany: The New Wirtschftswunder?," Chapter V of German Unification: Economic Issues, Leslie Lipschitz and Donogh McDonald, eds., IMF Occasional Paper No. 75, December.

McKibbin, Warwick J. (1990) "Some Global Macroeconomic Implications of German Unification," Brookings Discussion Paper in International Economics No. 81, The Brookings Institution, May.

(1992) "The New Europe and its Economic Implications for the World Economy," Economic and Financial Computing 2, 123-149.

McKibbin, Warwick J., and Jeffrey D. Sachs (1991) Global Linkages: Macroeconomic Interdependence and Co-operation in the World Economy, Washington: The Brookings Institution.

Wyplosz, Charles (1991) "On the Real Exchange Rate Effect of German Unification," Weltwirtschaftliches Archiv 127, 1-17. 
Table 1. East Germany: Composition of GDP

(Annual growth rates, in percent)

\begin{tabular}{lrrr}
\hline & 1992 & 1993 & 1994 \\
\hline Gross domestic product & 7.8 & 5.8 & 9.2 \\
& & & \\
Domestic demand & 15.0 & 5.4 & 7.7 \\
Private consumption & 9.6 & -1.2 & 4.5 \\
Government consumption & 6.8 & 14.1 & 16.5 \\
Investment & 27.8 & -199.2 & -210.8 \\
& & 5.5 & 22.6 \\
Foreign trade balance & & 5.5 & 9.4 \\
Exports & 189.9 & & \\
Imports & 10.2 & & \\
\end{tabular}

Source: Statistisches Bundesamt.

1. In DM billion. 
Table 2. Transfers to East Germany

(In DM billion)

\begin{tabular}{|c|c|c|c|c|c|c|}
\hline & 1991 & 1992 & 1993 & 1994 & 1995 & \\
\hline \multicolumn{7}{|l|}{ Gross transfers } \\
\hline Federal Government & & 75 & 88 & 114 & 128 & 151 \\
\hline Western Laender & & 5 & 5 & 10 & 14 & 14 \\
\hline German Unity Fund & & 31 & 24 & 15 & 5 & -- \\
\hline European Union & & 4 & 5 & 5 & 6 & 7 \\
\hline Fed. Labor Office & & 24 & 25 & 15 & 14 & 14 \\
\hline Pension Insurance & & $\overline{--}$ & $\underline{5}$ & 9 & $\underline{14}$ & $\underline{14}$ \\
\hline Total & & 139 & 152 & 168 & 181 & 200 \\
\hline \multicolumn{7}{|l|}{ Receipts } \\
\hline Taxes and fees & & 33 & 37 & 39 & 42 & 45 \\
\hline Net transfers & & 106 & 115 & 129 & 139 & 155 \\
\hline \multicolumn{7}{|l|}{$\begin{array}{l}\text { Net transfers as } \\
\text { a percentage of: }\end{array}$} \\
\hline West German GDP & & 4.0 & 4.1 & 4.5 & 4.7 & 5.0 \\
\hline East German GDP & & 51.4 & 43.8 & 42.3 & 40.5 & 40.6 \\
\hline
\end{tabular}

Source: Deutsche Bundesbank, Monthly Report, July 1995. 
Table 3. Germany: General Government Finances

(In percent of GDP)

\begin{tabular}{lrrrrrrr}
\hline & 1990 & 1991 & 1992 & 1993 & 1994 & 1995 & \\
& & & & & & & \\
& & & & & & & \\
Expenditure & 40.4 & 48.9 & 49.6 & 50.5 & 50.1 & 50.6 \\
Revenue & -1.9 & -3.3 & -2.9 & -3.3 & -2.5 & -3.6 \\
Fiscal balance & & & & & & \\
\hline
\end{tabular}

Source: IMF, World Economic Outlook database. 
Table 4. MULTIMOD Simulations of German Unification: Assumptions Concerning the Fiscal Cost and Increased Net Imports of East Germany

(In billions of 1990 DM;

percent of trend West German GDP in parentheses)

\begin{tabular}{|c|c|c|c|c|}
\hline & $\begin{array}{c}\text { Fiscal Transfers From } \\
\text { West Germany } \\
\end{array}$ & \multicolumn{3}{|c|}{$\begin{array}{l}\text { Increased Net Imports of } \\
\text { East Germany }\end{array}$} \\
\hline & $\begin{array}{lc}\text { Reference } & \text { Less optimist } \\
\text { case } & \text { scenario } \\
(1) & (2)\end{array}$ & $\begin{array}{l}\text { R } \\
\text { case } \\
(3)\end{array}$ & $\begin{array}{l}\text { Less c } \\
\text { scenari } \\
(4)\end{array}$ & \\
\hline 1990 & 95 (3.9) & 95 (3.9) & $116(4.7)$ & $116(4.7)$ \\
\hline 1991 & 78 (3.1) & $94(3.7)$ & $127(5.0)$ & $122(4.8)$ \\
\hline $1992-74$ & 42 (1.6) & $71(2.6)$ & $101(3.7)$ & $103(3.8)$ \\
\hline $1995-97$ & $23(0.8)$ & 53 (1.8) & $71(2.5)$ & $81(2.8)$ \\
\hline $1998-2000$ & $-3(-0.1)$ & $41(1.3)$ & $31(1.0)$ & 59 (1.9) \\
\hline 2001 & $-19(-0.6)$ & $33(1.0)$ & $5(0.2)$ & $43(1.3)$ \\
\hline
\end{tabular}

Source: McDonald and Thumann (1990), Tables 3 and 6, and calculations based on World Economic Outlook database. 


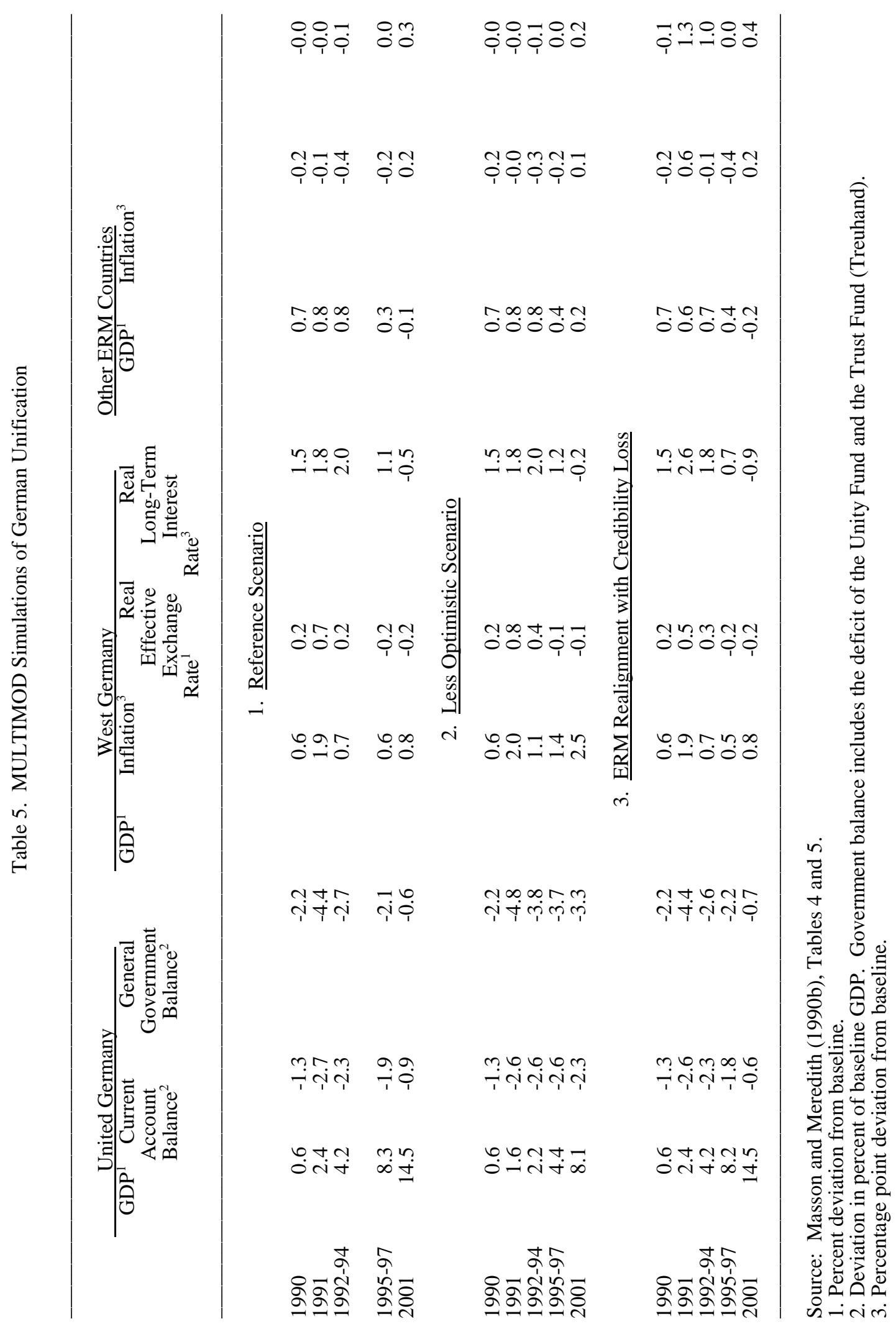




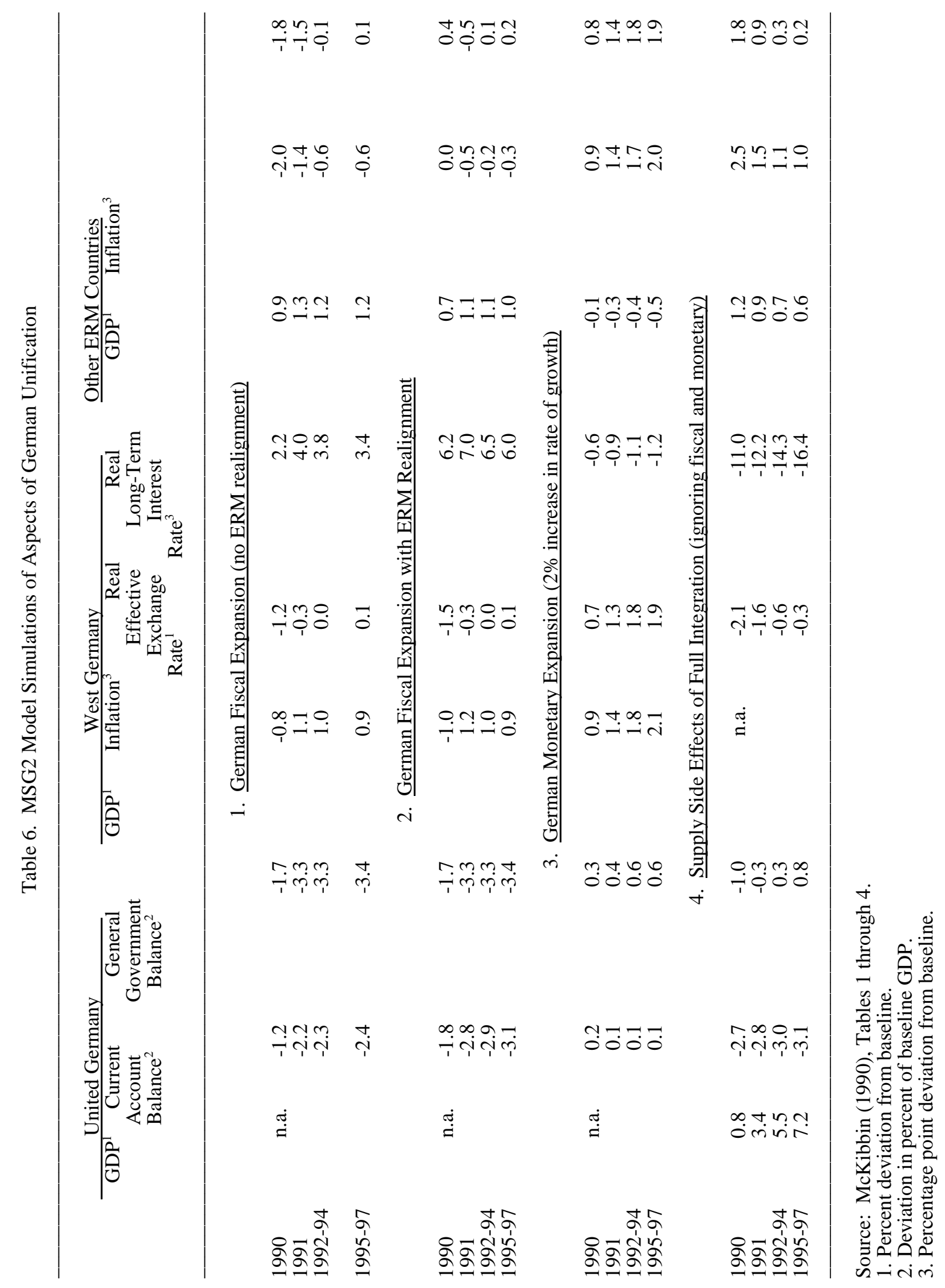




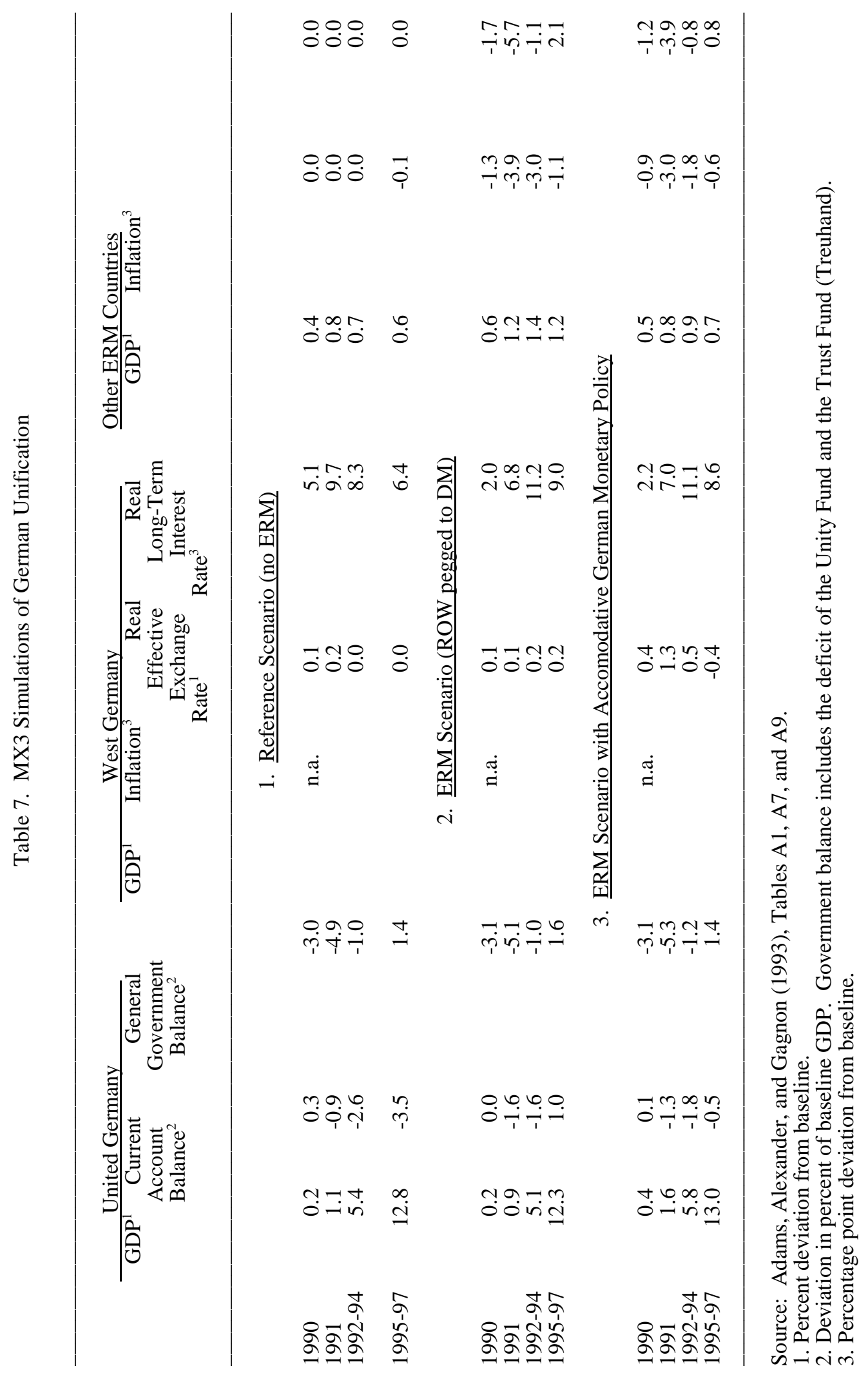




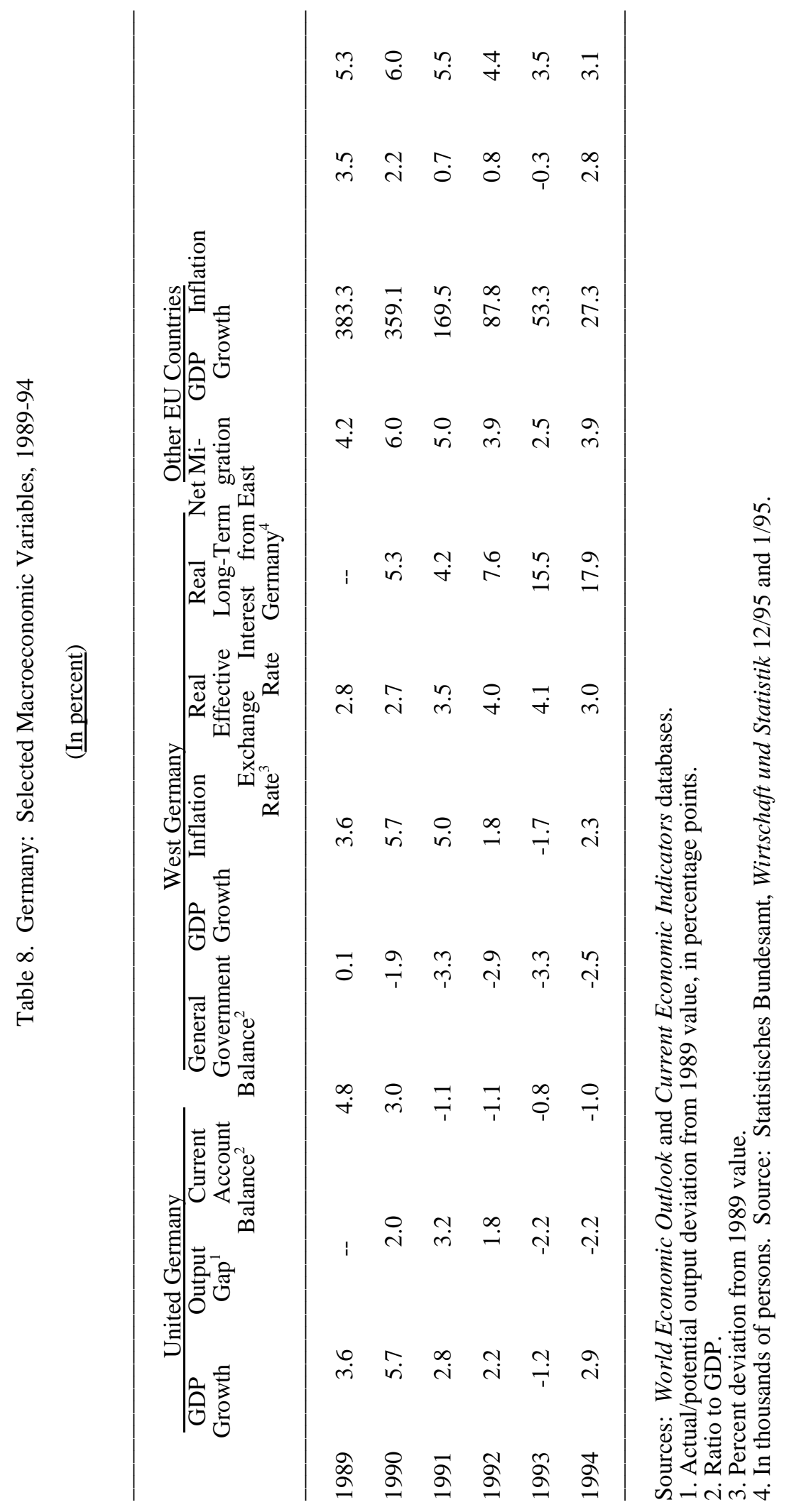

